\title{
PUBLISHING AND PRINTING COMPLEX: DIRECTIONS OF ECONOMIC DEVELOPMENT
}

\author{
Svitlana Gutkevych ${ }^{1}$, Lina Shenderivska ${ }^{2}$ \\ ${ }^{1}$ National University of Food Technologies, Educational and Scientific Institute \\ of Economics and Management \\ ${ }^{2}$ National Technical University of Ukraine "Igor Sikorsky Kyiv Polytechnic Institute", \\ Faculty of Management and Marketing
}

\begin{abstract}
The article aims to determine the current areas of economic development of publishing and printing companies that meet the requirements of economic digitalization. According to the results of content analysis of modern publications, effective ways of development implemented in branch enterprises are determined. In order to identify priority measures for publishing and printing companies with competitive potential and prospects for the industry development, a SWOT analysis is applied. The SWOT analysis revealed that potentially productive ways of enterprise development are expanding the range of products and services, improving their quality in the publishing and printing complex; integrating industry entities into the digital information environment, accessing international markets; state support in the implementation of measures to promote reading. It is determined that ensuring enterprises' efficiency requires the implementation of stages of effective enterprises development. Information support is necessary for making quality management decisions, respectively, to achieve the goals of development management. Resource potential combines a rational policy of supply and usage of financial, logistical, and labor resources. Organizational support aims to create an organizational structure in accordance with the purpose and objectives of enterprise management. The management of publishing and printing enterprises development aims at the transition to a new quality state, increasing earning capacity, competitiveness, extending the life cycle, mutually beneficial integration with the subjects of creative industries.
\end{abstract}

Keywords: development, digitalization, earning capacity, management functions, printing, publishing, SWOT-analysis

DOI: $10.17512 /$ znpcz.2021.3.02

\section{Introduction}

The publishing and printing complex as a component of the media industry should implement strategies for integration into the digital information environment, as the Internet is becoming a priority means of communications. This does not preclude the need for proposals in the market of printed publications but instead requires their improvement, increasing the level of services.

The digitalization of the information environment has caused significant production and technological, promotional, and distribution changes in the publishing and

${ }^{1}$ Svitlana Gutkevych, Doctor of Economics, gutkevych@ukr.net, ORCID: 0000-0003-2645-4011

${ }^{2}$ Lina Shenderivska, PhD, lina.shenderivska@gmail.com, ORCID: 0000-0003-3104-9803 
printing industry. Zhenchenko M. (2018, p. 233) notes that most print media have an online version, which becomes the main channel of access to the content of newspapers and magazines; smartphones and tablets have prospects as technological platforms for the content consumption, especially mobile versions of newspapers' and magazines' sites.

Gutkevych et al. (2021, p. 184) substantiate the directions for increasing the investment attractiveness of publishing and printing companies: increasing the level of knowledge intensity creates an added value and rises production competitiveness; creating joint products with the film and TV industry, as well as other creative industries builds synergy.

In the process of enterprise development, environmental safety issues must be addressed. The topical tasks for the publishing and printing business are the usage of paper with a larger share of secondary raw materials (recycled paper) and usage of less harmful inks and solvents to minimize waste and give priority to their processing (Clark 2014).

Timothy Fabling (2017, pp. 54-56) provides recommendations for an effective offer of a print-on-demand service and explains its prospects primarily for old classics; emphasizes the critical importance of the time factor for the supply of books to ensure the competitiveness of book products and points to the need to study and implement the world's leading experience in publishing.

The following features should be taken into account when developing a printing strategy: consumers want to work with companies that are constantly improving; to avoid reducing the volume of print advertising it is necessary to combine print and digital advertising so that they complement each other (Trench 2018).

The development of digital commerce will help to avoid several problems in the field of book trade services that might arise from the monopolization of the book trade market at the level of several players and the possibility to organize the sales channel through supermarkets only for bestsellers and by publishers with large marketing budgets (Saha, Lente 2020, pp. 28-30).

The purpose of the study is to determine the directions of economic development for publishing and printing companies.

\section{Methods}

First of all, in order to substantiate the relevant development directions of publishing and printing industry subjects', the industry features are identified. At the next stage of the study, management functions are analyzed; this is necessary because the development of enterprises is a managed process. Management functions are studied in the context of a publishing and printing complex. Taking into account its economic, social, environmental, and technological features is necessary because management is applied to a particular industry.

In selecting the literature for content analysis, several criteria are taken into account, namely, the review of modern international research in the field of management of enterprise development allows to identify current tasks for the enterprises of the publishing and printing complex and to apply the method of benchmarking - 
to find and offer for implementation progressive directions of economic growth of publishing houses and printing companies. Coverage of digitalization issues is necessary to justify competitive strategies. SWOT analysis is used for the structural characteristics of the subject of inquiry. Methods of observation and description of the subject area are applied.

\section{Production connections in the publishing and printing complex}

Publishing and printing complex is a set of business entities with a developed system of production relations for the creation, editing, reproduction, distribution of printed, electronic, multimedia content, united by a common goal - to meet the information needs of the population, enterprises, institutions, organizations.

The peculiarity of the enterprises of the publishing and printing complex consists in the complementarity of the complex components - publishing houses, printing houses, book trade organizations. After all, despite the intensive digitalization of information communications, there is a demand for printed publishing products, so publishers cooperate with printing houses - replicate products, and in the development of direct distribution channels, including digital, they retain their important intermediary, online and stationary bookstores, etc. Thus, the competitiveness of publishing products in the media market depends on the effectiveness of the interaction between subjects of publishing and printing complex, the development of their cooperation forms.

Conventionally, the publishing and printing complex includes the author's and readers' environment. The task of the publishing house is to find relevant topics, interesting authors, to see the advantages of the author's final manuscript, and in the process of editorial and publishing preparation at the stage of promotion to emphasize and strengthen them, encouraging both intermediaries and end-users to purchase. The task of the printing house is to provide consulting support to the publishing house at the stage of the technical design of the publication; promptly, qualitatively, in accordance with the terms of reference, and in compliance with standards to replicate the publication. The task of the sales link is to provide advisory support to customers, quickly orient them on the assortment and the content of publications, duly replenish the assortment and deliver products to consumers, tracking and informing about the status of the order, promotional offers, new products, and services; thus, building effective communications with customers; and finally to give timely feedback to publishers on current consumer inquiries.

All enterprises are objects of management and in modern conditions have their own development goals, including strategic ones. For effective activity, it is necessary to manage enterprises on the basis of a development strategy.

\section{Stages of effective enterprises development}

From a scientific point of view, management is the organization of the movement of resource flows to ensure the functioning of the system based on the definition of goals and use of resources (Omelianenko, Osokina 2016, p. 30). Scientists define management as a process and indicate that management is carried out depending on 
the enterprise potential and is defined as a systematic, planned, and targeted impact on resource potential to increase its earning capacity and enterprise competitiveness (Okafor Obiefuna 2014, p. 94; Sumets 2021, p. 12).

As a process, enterprise management is based on the influence of the subject of management on the object; the subjects are owners and managers at all levels of enterprise management; and the object is the process of quantitative, qualitative, and structural changes occurring at the enterprise (Kovalenko 2019, p. 104).

We have identified the stages associated with ensuring the effective development of enterprises: information support, formation, development, usage of resource potential, organizational support, which ultimately allows achieving goals. As the analysis showed, at the stage of information support of development management the analysis of a condition of the enterprise and external environment is carried out. The functions of information support include determining the need for change, setting goals and objectives of development management. In order to obtain up-to-date information, the external and internal operating environments should be monitored on an ongoing basis. In the second stage, in order to rationally provide resources, measures are developed and implemented to improve the efficiency of the supply and consumption of resources. The third stage - organizational support - involves the construction of the organizational structure and on its basis the construction of management functions, taking into account the development of such a system of work motivation that will contribute to achieving the management goal of enterprise development.

Based on the fact that the organizational structure is a composition of departments for the main, ancillary production and services, and the management structure shows coordination in the organization to achieve goals and objectives, consider such typical management structures as linear, functional, linear-functional, program-targeted, matrix, and divisional (Shkrobot, Saloid 2020, p. 42). The linear management structure provides a clear division of functions between line managers, and each manager is subordinated to a single manager, which ensures the efficiency of decision-making and increases the responsibility of the head of each department for the results of work. This type of structure is typical for small businesses.

Expansion and complication of tasks to be solved by the company's management motivates the creation of a functional structure in which an individual executor can be subordinated to several functional managers. When creating a linear-functional structure, each employee is subordinated to one manager to deal with administrative issues, and at different levels of management, there are inter-functional divisional connections (Shkrobot, Saloid 2020, p. 63).

For types of economic activity, where constant implementation of new projects is typical, the program-target structure can occur both at the stage of enterprise creation and in their development. In modern conditions, the program-target structure begins to be implemented in the publishing and printing industry, and the team may include a technologist, sales manager, and economist. Program-targeted structures are common in the publishing industry and the other branches of the media industry. For example, in a publishing house, the team includes the editor-in-chief, the literary 
editor, the art editor, the proofreader, and employees who will prepare the publication for circulation. To ensure management flexibility, based on a combination of program-target and linear structures, the matrix management structures are implemented to ensure effective usage of professional knowledge of employees involved in temporary projects, while maintaining their linear subordination (Shkrobot, Saloid 2020, p. 71).

Of particular interest to small and medium businesses is the divisional structure. This structure is effective in creating business associations and diversifying production. A divisional structure provides for the centralized performance of several functions, such as financial management, strategy development, and operational management functions are transferred to production departments. With a divisional structure, the number of managers increases, but the development of certain product areas of enterprises is ensured.

Changes in the organization of management occur throughout the life cycle. When creating enterprises, the management structure is simple, and linear, with functional or linear-functional structures prevailing. In the process of enterprise development, the structure is adapted to environmental conditions. The growth of enterprises requires the involvement of additional resources, including labor. Because it is fixed in certain market segments (Balbazan 2014), specialists in the relevant areas are involved. Upon reaching middle-aged enterprises, specialists have acquired specific knowledge about the characteristics of a particular enterprise, have sufficient experience, thus the management is decentralized, and the rules and job descriptions are applied. The maturity of enterprises is characterized by an increase in professional and service departments, tightening management regulations (Balbazan 2014). In the fifth stage, enterprises are aging, economic efficiency is declining, the financial condition is deteriorating, which requires greater centralization of management. In order to revive enterprises, a radical restructuring of business processes is carried out and additional specialists may be involved.

Type of management is important for enterprise development. There are such types of management as control by deviations, by results, by excitations, adaptive control by results with the prevention of the influence of external destabilizing factors (Zelenska, Krush 2013, p. 63). To maximize economic results, enterprises should take measures to prevent destabilization.

The management of enterprises is influenced by methods, approaches, functions, and principles. One of the methods of management of enterprise development is a balanced system of indicators aimed at improving operational efficiency - improving product quality, reducing the production cycle duration, reducing costs, etc. (Pestovska, Grytsenko 2017, p. 27). The effectiveness of this method depends on a sufficiently comprehensive and objective assessment of the existing system of indicators and these areas of activity that are of priority importance for product competitiveness, performance, as well as the organization of control and regulation. A balanced scorecard includes the following groups: finance, clients, training and career growth, internal business processes and is formalized by a linear function: 


$$
\mathrm{y}=b+\sum_{i=1}^{n} a_{i} \cdot x_{i}
$$

In terms of increasing consumer demands for product quality, quality management is relevant, that is a systematic approach to solving the problem of defect prevention, based on the detection, evaluation, elimination of defects, maintaining the stability of the production process (Nanka et al. 2019, p. 192).

The quality of management of enterprise development affects their economic development. Under favorable conditions, the development management aims to maximize profits in the short term. In a crisis, it is necessary to save resources to save businesses, so measures that are not inherent in the management of favorable environmental conditions are implemented, namely, the introduction of strict cost control, and the maximum centralization of management (Vasiutkina 2014, p. 36). It allows maintaining the market share.

\section{Development management in the publishing and printing complex}

Increasingly relevant in today's domestic economy is managing the development of printing companies, due to their importance to society to meet its information needs and provide access to quality printing products, as well as several features such as connection with publishing activities, cooperation with individual and corporate consumers, labor intensity and complexity of production, low wages, and consequently, work motivation, the need for highly skilled workers, high cost of printing equipment, material consumption, and import dependence.

Management of enterprise development in modern conditions requires and allows to solve the task of increasing the demand for products on the basis of the rational usage of own resources and attracting additional investment resources, improving product quality, implementation of scientific and technological progress, adaptation to unstable market conditions.

The development and implementation of management of publishing and printing companies aimed at improving the efficiency of activities should take into account the need for development management as a process based on functions, methods, approaches, directions, and principles. Enterprises need to perform a set of basic management functions, namely, planning, organization, motivation, analysis, and control.

On the basis of planning the values of indicators that need to be reached, current and the prospective possibilities of the enterprise are specified, taking into account operating conditions. In the planning process, it is necessary to anticipate the risks that may arise in achieving the goals in order to establish an action plan and rationally allocate the necessary resources (Giraud et al. 2011, p. 5). Internal risks are managed and they include organizational, legal, and financial risks (Przesmycka, Podstawka 2015, p. 159).

There are different kinds of planning: short-term - operational, medium-term budgeting, and long-term - strategic (Giraud et al. 2011, p. 5). In general, the high rate of scientific and technological progress, and hence changes in the environment 
of enterprises, reduce the time of strategic planning to 3-5 years, and at the same time require systematic revision and adjustment of plans. In the process of analyzing alternative strategies, it is necessary to justify the priority strategy and the so-called „fall-back" option, which can be implemented quickly if the priority strategy proves ineffective.

Establishing realistic targets is possible if forecast estimates are objective. One of the most common forecasting methods is the method of trend extrapolation, which assumes that the trend identified in previous periods will continue in the future; so, taking into account economic instability, it is advisable to give interval estimates of forecast indicators. Forecasting can also be carried out using the method of expert assessments, to increase its objectivity, it is necessary to give preference to collective assessments, carefully select specialists, provide a sufficient number of experts.

In the conditions of economic digitalization, planning of enterprise activity, it is necessary to take into account the digitalization of the environment. Business entities created in modern conditions, in their mass, are based on digitalized technologies, and can also cover all areas of activity, and what is critical in a pandemic - sales. This vector development affects the investment policy because in the conditions of the high frequency of information updates it is necessary to provide technical support and modernization of information channels, as well as constant investment flows, especially in intangible assets.

The following integration processes in the digital environment are relevant:

- between publishers, printers, software developers for product upgrades - production of printed publications with elements of augmented reality, virtual reality, with QR-codes-links to sites with video, music, etc., so the printed edition acquires the advantages of multimedia; for modernization of sites taking into account modern trends in web design, the needs of the target audience: language, font, visual, stylistic, compositional perception;

- between publishing houses, printing houses, book trade organizations, and other participants of the ecosystem of publishing and printing business and software developers for automation of workflow management: order acceptance processes, logistics, financial support, maintenance, training, sales, management, which together allows to reduce the duration of financial and production cycles, to increase quality, to release time from routine operations and to use it for the realization of creative potential, advanced training;

- between the subjects of the publishing and printing complex and the owners of digital platforms and their content. The usage of digital marketing is a necessary area of product promotion. Digital marketing includes digital television, text messaging, radio, billboards (electronic boards, printed billboards with QR-codes of links to Internet resources); Internet marketing (social media, content marketing, banner advertising, email marketing, mobile devices); search marketing (SEO, PPC - pay per click) (Minculete 2018, p. 64);

- prompt development and wide coverage of digital channels allow to find customers quickly, keep in touch with all customers, offer relevant and requested proposals, maximize personalization and targeting; 
- digital marketing also involves consumer analytics. For the subjects of the publishing and printing complex, it is a source of information for further improvement of the assortment policy, positioning, and development of the sales network. According to the results of the analysis of media metrics (clickability of titles, duration of reading materials, frequency of site visits, distribution of the number of site visits by the time of a day, number of readers, headings, etc.) the content, its rubrication and site navigation are improved. This is especially relevant for online media. Indicators of mediametry are taken into account in media planning;

- between the subjects of the publishing and printing complex and the owners of educational online platforms, this is another promising area of economic development of the subjects of the publishing and printing complex, because the usage of marketing communication channels already established by the platforms projects of the publishing and printing complex, access to professional technicaltechnological and methodical base promotes the development of high-quality educational products;

- between the subjects of the publishing and printing complex in professional online communities. Professional communities, such as LinkedIn, help solve common problems for participants, provide each other with free consulting support, and form new business relationships.

When planning the development of publishing and printing companies, it is necessary to take into account a number of features, namely, the priority of innovative development, which is associated with increased intra- and intersectoral competition; the expediency of expanding the scope of activities through cooperation, which is relevant in the context of funding shortages; multivariate directions of development and complication of the operating environment, which requires careful forecasting and justification of the priorities of enterprises; the need to reload existing production capacity. In the enterprises of the publishing and printing complex, insufficient attention is paid to planning to determine the prospects for development. Therefore, changes implemented in the publishing and printing industry are mainly a reaction to events that have occurred and are not preventive in nature. Moreover, the changes that are planned are not related to complex, but to individual activities.

The function of the organization is complex: it includes the organization of production and labor and provides a rational combination in time and space of all resources. The implementation of all processes necessary to achieve development goals (Evdokimov, Pushkarev 2020, p. 649), with the constant change of customer needs, increasing the level of their requests, effective development is possible on the condition that flexible progressive production is provided by the appropriate formation of the technical and technological base, training of employees in related professions to ensure their interchangeability. The creation and development of technical and technological base should take into account the assessment of current and future needs of consumers and their compatibility with the technical capabilities of the enterprise, the cost, and the availability of material resources. Intensive changes of technologies and forms of cooperation with suppliers of resources require the revision of the basic norms and standards of the enterprise. 
To ensure one of the key factors in the competitiveness of printing production operativity, it is advisable to follow a parallel or combined cycle, group orders to start production on the principle of minimizing time to reconfigure equipment, properly agree with the customer terms of reference that reduce production risks. Reducing the duration of orders is also achieved by automating both production and management processes, and requires sufficient funding, employee competency level, and adherence to work discipline. The continuity of production is achieved through the establishment of round-the-clock work, the development of measures to reduce the risk of disruption of the production cycle, in particular, the selection of alternative suppliers of material and technical resources, timely preparation of materials for consumption, and cooperation with industry. The usage of digital technologies, including mobile applications for receiving orders, distribution of logistics flows, planning the geography of development of production, and distribution networks these are the necessary conditions for competitive production.

The function of the organization aims to build an organizational management structure that will ensure the effective achievement of enterprise goals, and in the diversification of activities and the creation of corporations, it is necessary to avoid duplication of tasks, to coordinate decisions, and to develop a common economic policy. The organizational structure is built taking into account the scale of the business, the development of certain activities, and the complexity of the tasks to be solved. In modern conditions, program-target structures are becoming widespread, and collegial decision-making is developing.

Motivation, as a function of management, aims to stimulate employees to achieve the goals of the organization, which allows them to meet their own needs. For effective work motivation, it is important to link the goals of the organization with personal interests, to establish effective communication between experts, to create teams, and to distribute responsibilities according to the skills, knowledge, and competencies of employees (Terziev 2018, p. 711).

Personnel management can be carried out on the basis of substantive or procedural concepts of motivation. According to meaningful concepts, staff should be motivated taking into account their needs, hierarchy, as well as the diversity of the reward system. According to procedural concepts, it is necessary to take into account the individual perception of remuneration by employees, as well as the dependence of employee behavior on the expected consequences.

The most important for employees are financial incentives, with the exception of young employees/students, for whom the priority is gaining experience, so they can agree to a low level of wages. In any case, it is necessary to objectively assess the performance of employees, to fairly determine the contribution of each employee, to avoid discrimination, to adhere to the legal framework for remuneration and work schedule. Employees should be informed about their job responsibilities, as well as the system of bonuses and penalties for violations of labor discipline. In the knowledge economy, one of the priority ways of motivation can be staff training, encouraging self-education. Socially responsible companies plan and organize staff training. The organization of knowledge exchange between employees helps to increase their competence and the quality of work. But for this, first of all, managers 
must demonstrate leadership qualities, strive for continuous training and self-improvement, work for the benefit of clients, and support the employees (Shenderivska 2019, p. 39). It is expedient for enterprises to create conditions for intrapreneurship. Progressive incentive systems include employee participation in the distribution of enterprise profits. In modern conditions, special attention should be also paid to stimulating innovation to ensure the progressive development of enterprises. Stimulation of innovation is associated with a number of features, namely, the significant duration of the innovation process, the need to assess the intellectual work and contribution of each participant to the collective result, the application of an individual approach to identifying the needs of employees involved in creative innovation.

The next management function - control - involves the analysis of the implementation of decisions and the achievement of targets. The condition for effective control is quality planning (Giraud et al. 2011, p. 4). Control is necessary for the timely identification of threats and opportunities, the search for new ways to achieve the goals of the enterprise, so the control is carried out both at the stage of planning, strategy development, and in the current activities of the enterprise. Control should include identifying the causes of deviations from the planned values of indicators, as well as the development of an action plan to regulate the activities of enterprises. The peculiarity of control as a management function is in the direction of information, as the manager or other entity receives information from the object of management (Terziev, Banabakova, Ilsheva 2017, p. 143).

It is necessary to create a system of control indicators, frequency of control, as well as to appoint people responsible for achieving indicators and work stages. The main control indicators include the volume of marketable products, income, profit, enterprise costs, product profitability, market share, etc. both in absolute terms and in dynamics, compared to the planned or recommended level, which is primarily relevant for financial analysis. An important task of control is to determine the costeffectiveness of the enterprise, which should be carried out by individual units; therefore, the use of functional-cost analysis is promising. The control function in the context of the COVID-19 pandemic became especially relevant, as the decline in business activity required a rapid search for ways to reduce costs, which allowed to identify the factors of overspending and optimize the cost management system.

Supervisory control over the current course of the production process is relevant for enterprises. In modern conditions, its implementation may involve customer service managers who are responsible for passing the goods in production. A promising area for improving supervisory control is the introduction of automated production management systems at enterprises. They are essential in remote settings for administrative staff and managers and when working with clients.

Prospects for enterprise development depend on the level of customer satisfaction. Continuous monitoring of consumer loyalty is a common guideline for managing changes in the enterprise. The reasons for customer dissatisfaction cannot always be identified, because consumers, intermediaries, sellers are not always reporting. Therefore, most attention should be paid to the analysis of calls to the call center of the enterprise, monitoring responses and dislikes in social networks and Internet 
resources of the enterprise, comments in messengers, and the number of returned goods. It is necessary to systematically organize customer surveys. Automation of these processes makes it possible to increase the quality and efficiency of communication with consumers.

The integration of management functions, their focus on the maximal use of development opportunities, and prevention (reduction) of operational risks contribute to the implementation of the concept of enterprise management as a system that is constantly learning and improving, thus developing.

As already noted, the peculiarity of small businesses, compared with mediumsized businesses, is that some specific functions, in particular, marketing, technical, and legal services of enterprise production are not developed independently, but outsourced to other organizations on terms of outsourcing, due to the inability to provide stable funding to keep permanent staff. The function of input quality control of raw materials is also not fully performed, and operational control is carried out mainly without the involvement of specialists. The experience of Chinese printing houses is progressive to follow, creating associations that centrally perform the function of quality control, and some printing houses also create quality control departments or appoint a quality control specialist/technologist.

An important factor in effective management is the provision of information about the internal and external environment. Based on the analysis, it is determined that the function of marketing research is insufficiently performed in enterprises; the main attention is paid to the study of the level of existing consumers' needs satisfaction and not to the identification and stimulation of new needs. Positive trends in companies' interaction with the external environment include the proliferation of direct marketing and the improvement of customer collaboration by delegating the power to control the ordering process to print company managers to work with customers. At the same time, the management does not pay enough attention to other promising areas of product promotion, in particular, digital marketing.

We analyzed the general management methods used in publishing and printing companies, the results of which established a number of features. The analysis of administrative management methods in publishing and printing companies has shown that there is not always a clear division of responsibilities, and it negatively affects the quality of products and performance of certain functions. The liquidation of labor rationing departments at printing enterprises has negatively affected the level of labor organization, thus, outdated local norms or branch norms that are not adapted to the conditions of specific enterprises are applied in production. The abolition of the position of accountant in publishing houses will lead to the transfer of these functions to the director, marketer, or manager.

Economic management methods are more developed in medium-sized enterprises, which in their work are guided by the provisions on bonuses. The payment of bonuses in small businesses is unsystematic due to the unstable amount of funding and depends on the decision of the head to distribute funds between different areas of development, which negatively affects the motivation to work. At the same time, 
to increase the level of social protection of workers, printing companies are introducing an hourly form of wages for workers, which helps to stabilize wages in underemployment. In the context of the COVID-19 pandemic, which led to a reduction in activity, companies offered employees barter, such as advertising the services of a full-time designer, web analyst, etc. on the company's Internet resources. In this way, businesses maintained skilled workers, while allowing them to earn extra money from other employers.

The development of enterprises depends on the effectiveness of socio-psychological methods. For effective internal communication, companies create conversations in Telegram, groups in Viber, use Internet platforms such as Zoom, Google Meet, and more. This contributes to a higher level of awareness about the current state of the enterprise and ongoing changes, which reduces resistance to change. Dissemination of professional content development has a positive effect on the quality of the team as a whole. Balanced communication when management should share progressive innovative knowledge as well as encourage employees to bring innovative proposals to well-known managers expands progressive experience from colleagues.

Based on the analysis, a low level of automation of production management in publishing and printing companies is revealed, which complicates the scheduling of production in modern conditions, characterized by the increased number of order names and reduced circulation, complicated order designs, and the increased requirements for efficiency. In the production activity of publishing and printing enterprises, the complex usage of automated control systems (ACS) is carried out or only some functions are automated, which is mainly related to the development of route-technological maps, as well as costing and accounting. We have identified factors that limit the implementation and full usage of automated production management systems - lack of funding, insufficient assessment of management benefits of automation of management processes, low level of training to work with such systems, unwillingness to change the company, and business ecosystem.

The current direction of development of the publishing and printing complex is the improvement of material and technical supply, namely paying more attention to stock rationing, level of payment discipline, search for reliable suppliers, automation of communications, and implementation of a reminder policy for timely replenishment. It is worth paying attention to the progressive supply systems "Just in Time", "Just in Time 2".

As the analysis showed, in modern conditions at the publishing and printing complex the number of the management staff is reduced, which leads to the uncertainty or deterioration of certain functions, namely, quality control of production, production scheduling, control over the implementation of decisions and others, due to economic costs on the use of personnel, but negatively affects the competitiveness of products. Insufficient attention is paid to the search for new areas of activity, the management functions are not performed on a systematic basis, skills of administrative staff and other labor resources are sporadically improved. Table 1 presents a SWOT analysis of a publishing and printing complex. 
Table 1. SWOT-analysis of the publishing and printing complex

\begin{tabular}{|c|c|c|}
\hline Origin & Strengths & Weaknesses \\
\hline Internal & $\begin{array}{l}\text { - experienced staff } \\
\text { - developed intellectual potential } \\
\text { - developed technical and technolog- } \\
\text { ical potential for the production of } \\
\text { a wide assortment of products } \\
\text { - the small size of enterprises makes } \\
\text { them flexible and sensitive to } \\
\text { innovation }\end{array}$ & $\begin{array}{l}\text { - passivity in entering international } \\
\text { markets } \\
\text { - unbalanced automation of } \\
\text { workflow management in the } \\
\text { subjects of publishing and printing } \\
\text { complex } \\
\text { - insufficient attention to improving } \\
\text { the skills of management staff }\end{array}$ \\
\hline & Opportunities & Threats \\
\hline External & $\begin{array}{l}\text { - high level of demand for high- } \\
\text {-quality electronic, multimedia } \\
\text { publications and in general for } \\
\text { quality publishing products, } \\
\text { printing products (packaging, etc.) } \\
\text { - high level of demand for new } \\
\text { knowledge, information, including } \\
\text { niche and multidisciplinary content } \\
\text { - available technologies of cost- } \\
\text {-effective production of low- } \\
\text {-volume products (digital printing) } \\
\text { - greater attention to eco-friendly } \\
\text { products }\end{array}$ & $\begin{array}{l}\text { - small volume of the domestic } \\
\text { market } \\
\text { - reduction of output of printed } \\
\text { publishing products } \\
\text { - high level of competition } \\
\text { - reduction the interest of younger } \\
\text { generations in reading literature } \\
\text { - decrease of the stationary book } \\
\text { trade }\end{array}$ \\
\hline
\end{tabular}

Source: Authors' own study results

The publishing and printing complex has a developed intellectual capital, which determines the prospects of development - it is training, lectures, seminars to disseminate progressive experience in publishing; selection of current news on the requested topics, their distribution by subscription, preparation of current audio publications.

A developed technical and technological potential stimulates the expansion of the range of products, including corporate printed products, environmentally friendly packaging. The digitalization of the information environment encourages publishers to independently acquire competencies or develop production links to increase the production of electronic and multimedia publications. This creates new, multidisciplinary requirements for the training of publishing professionals - from specialized knowledge in the field of editorial, printing, distribution processes, to deepen the level of technical training to create products using modern digital technologies, knowledge in economics, and promotion. Directors, editors-in-chief of publishing houses should be well versed in the field of marketing, including digital; current topics, reader needs, and consumer inquiries about the service.

The small domestic market of publishing and printing products motivates a constant increase in the level of product quality, service, quality of management, access to international markets. To increase the level of service, it is advisable to use QR 
codes more actively in publications, to place QR codes at the root of books for the convenience of readers, to speed up the process of choosing a book, make it more convenient. The state's interest in the development of a highly intelligent educated nation requires public investment in the promotion of reading, the implementation of programs to support the publishing business of Ukraine, including in the international market.

\section{Conclusions}

Summarizing the theoretical foundations of the essence of development management, we propose to consider the concept of ,management of enterprise development" as a process of change to achieve the goals of enterprises, the transition to a new quality state, taking into account industry specifics and the need for integration into the digital environment.

The digital economy is transforming the information space: new categories of content producers are appearing - bloggers, any companies that are not registered as subjects of information activities; new forms of cooperation of bloggers and professional information market participants are developing; new business models and new methods of content monetization are being created. In these conditions, to ensure the competitiveness of the publishing and printing complex, it is necessary to maintain high-quality content, intensify product promotion, develop partnerships with content producers and other participants in the information market. Digital transformation of publishing houses and printing enterprises is necessary; it requires the adaptation of personnel to the new format of industrial relations and the encouragement to constantly increase the level of digital competencies. Digital transformations have a high level of capital intensity. In the event of a funding shortage, it is advisable to implement a step-by-step model of production digitization, giving priority primarily to these activities that are vital for consumers. Topical digital services for consumers are automatic order placement, the ability to automatically track the stage of order fulfillment, the notification system of the date of order execution, delivery, payment, services, promotional offers, selection, and proposition of relevant content for customers.

The modern knowledge economy provides opportunities for market participants to receive an additional source of income from the training delivery services. It is of current interest for publishers who prepare and deliver content at a high professional level and can teach it; for publishers, printing, and bookseller companies that have developed effective business models and can share their progressive experience.

The sphere of functioning of the publishing and printing industry - information environment, which is multiplicatively growing, rapidly becoming obsolete, is highly competitive, but at the same time large in volume and variety of information needs - all this requires a high level of flexibility of strategic management, early customer response, search for new information interests, multidisciplinary; as well as the courage of enterprises in production experiments. 
The given recommendations on the directions of development of publishing and printing enterprises are not exclusively local, they are expedient for application outside Ukraine, taking into account adjustments to the level of digital development of the industry, specifics of consumer information needs (for example, for many countries sports are the top topic), access to investment resources, participation of the country, enterprises in international associations.

Considered ways of development, namely, the introduction of innovations, expansion of cooperation forms and creation of associations, increase of competitiveness of production, improvement of service level, development of logistic potential, and the introduction of progressive motivation systems, etc., are topical for the enterprises of any size.

\section{References}

1. Balbazan V.S. (2014), Features of Life Cycle Concepts, http://repository.hneu.edu.ua/bitstream/123456789/5347/1 (accessed: 22.06.2021).

2. Clark A. (2014), EBRD Sub Sector Environmental \& Social Guideline, Printing and Publishing, https://www.ebrd.com > documents > environment (accessed: 02.05.2021).

3. Evdokimov V.O., Pushkarev O.N. (2020), Basic Approaches in Enterprise Management, "StudNet: Scientific and Educational Journal for Students and Teachers", No. 9, https://cyberleninka.ru/article/n/osnovnye-podhody-v-upravlenii-predpriyatiem (accessed: 10.05.2021). DOI: 10.24411/2658-4964-2020-1093.

4. Fabling T. (2017), Introducing Remote Printing into the Publishing Industry of a Small, Remote Economy: the Case of New Zealand, A thesis submitted to the Victoria University of Wellington in partial fulfilment of the requirements for the degree of Masters of Commerce, https://researcharchive.vuw.ac.nz/xmlui/bitstream/handle/10063/6208/thesis_access.pdf? sequence $=1$ (accessed: 06.05.2021).

5. Giraud F., Zarlowski P., Saulpic O., Lorain M., Fourcade F., Morales J. (2011), Fundamentals of Management Control, Pearson Education - France, Paris, https://www.pearson.fr/ resources/titles/27440100959280/extras/7519_chap01.pdf (accessed: 11.05.2021).

6. Gutkevych S.O., Sheremet O.O., Zavadskych G.M., Muzychenko G.G., Shenderivska L.P., Kobylyanska L.M., Rusan V.M., Kaira L.G., Boyko V.O., Korotun O.P., Maziar O.O. (2021), Investment Priority of Economic Sectors, Disa Plus, Kharkiv.

7. Kovalenko N.V. (2019), Development Management System of the Enterprise and its Components, "Problems of Systemic Approach in the Economy", Vol. 4(72). DOI: 10.32782/2520 2200/2019-4-15.

8. Minculete G. (2018), Approaches to the Modern Concept of Digital Marketing, "International Conference Knowledge-based Organization", Vol. 24(2), https://www.researchgate.net/publication/326651398_Approaches_to_the_Modern_Concept_of_Digital_Marketing/link/5b5b 191 ca6fdccf0b2fa6776/download (accessed: 14.06.2021). DOI:10.1515/kbo-2018-0067.

9. Nanka O.V., Antoshchenkov R.V., Kis V.M., Lystopad I.O., Moisieieva N.I., Halych I.V., Nykyforov A.O. (2019), Total Quality Management, HNTUSG, Kharkiv.

10. Okafor Obiefuna A. (2014), The Role of Top Management in Business Organizations, "Review of Public Administration and Management", Vol. 3(5), https://www.arabianjbmr .com/pdfs/RPAM_VOL_3_5/10.pdf (accessed: 24.06.2021).

11. Omelianenko T.V., Osokina A.V. (2016), Operations Management: Presentation Course, KNEU, Kyiv.

12. Pestovska Z.S., Grytsenko Ye.G. (2017), Enterprise's Financial Strategy Formation on the Basis of Balanced Scores System Modification, “Academy Review", No. (47), https://acadrev .duan.edu.ua/images/PDF/2017/2/4.pdf (accessed: 29.04.2021). 
13. Przesmycka A., Podstawka M. (2015), Zarządzanie ryzykiem w działalności przedsiębiorstw - wybrane zagadnienia, "Zeszyty Naukowe Uniwersytetu Przyrodniczo-Humanistycznego w Siedlcach. Administracja i Zarządzanie", nr 105, https://repozytorium.uph.edu.pl/bitstream/handle/11331/566/Przesmycka_Podstawka_Zarzadzanie_ryzykiem_w_dzialalnosci .pdf? sequence $=1$ (accessed: 27.04.2021).

14. Saha A., Lente S. (2020), Rethinking 'Diversity' in Publishing, Goldsmiths Press, London, https://www.booksellers.org.uk/BookSellers/media/Booksellers/Rethinking_Diversity_in_ Publishing-Full-Report.pdf (accessed: 03.06.2021).

15. Shenderivska L.P. (2019), Performance Management of Printing Enterprises, "Scientific Notes of the International Humanitarian University", Issue 31, https://docs.mgu.edu.ua/docs/ konferencii/sborniki/sbirnik312019.pdf\#page=34 (accessed: 20.05.2021).

16. Shkrobot M.V., Saloid S.V. (2020), Organizational Design: Lecture Notes, Igor Sikorsky KPI, https://ela.kpi.ua/bitstream/123456789/36607 (accessed: 18.04.2021).

17. Sumets O.M. (2021), Strategic Management, HNUVS, Kharkiv.

18. Terziev V. (2018), Importance of Human Resources to Social Development, "IJASOS International E-Journal of Advances in Social Sciences", Vol. 4(1)2, https://papers .ssrn.com/sol3/papers.cfm?abstract_id=3310508 (accessed: 25.04 .2021 ).

19. Terziev V., Banabakova V., Ilsheva M. (2017), Controlling as a Management Function of the Organization, "Challenges and Opportunities of Scientific Thought Development: Collection of Scientific Articles", https://www.researchgate.net/publication/319252788_Controlling as_a_Management_Function_of_the_Organization (accessed: 01.06.2021).

20. Trench R. (2018), Issues Facing the Print Industry and How to Overcome Them, https://sinalite .com/ printersuccess/issues-facing-the-print-industry-and-how-to-overcome-them (accessed: 14.04.2021).

21. Vasiutkina N.V. (2014), Management of Sustainable Development of Enterprises: Theoretical and Methodological Aspect, Lira K, Kyiv.

22. Zelenska M.O., Krush P.V. (2013), Management of the Printing Company Potential, NTUU "KPI", Kyiv.

23. Zhenchenko M.I. (2018), Digital Transformations of the Publishing Industry, Zhnets, Kyiv.

\section{KOMPLEKS WYDAWNICZY I POLIGRAFICZNY: KIERUNKI ROZWOJU GOSPODARCZEGO}

Streszczenie: Celem artykułu jest identyfikacja aktualnych obszarów rozwoju gospodarczego firm wydawniczych i poligraficznych, które spełniają wymagania cyfryzacji gospodarki. Na podstawie wyników analizy treści współczesnych publikacji określane są efektywne sposoby rozwoju realizowane w przedsiębiorstwach branży. W celu zidentyfikowania działań priorytetowych dla przedsiębiorstw z branży wydawniczej i poligraficznej, które spełniają potencjał konkurencyjny, perspektywy rozwoju branży, przeprowadzono analizę SWOT. Zgodnie z jej wynikami zasadne są: poszerzanie gamy produktów i usług, poprawa ich jakości w branży wydawniczej i poligraficznej, integracja podmiotów branżowych z cyfrowym środowiskiem informacyjnym, dostęp do rynków międzynarodowych. Niezbędne jest wsparcie państwa we wdrażaniu środków promujących czytelnictwo. Stwierdza się, że zapewnienie efektywności przedsiębiorstw wymaga realizacji etapów efektywności rozwoju. Wsparcie informacyjne jest niezbędne do podejmowania decyzji dotyczących zarządzania jakością, odpowiednio, tak aby osiągnąć cele zarządzania rozwojem. Potencjał zasobowy łączy racjonalną politykę zaopatrzenia i wykorzystania zasobów finansowych, logistycznych, pracy. Wsparcie organizacyjne winno być ukierunkowane na stworzenie struktury organizacyjnej zgodnej z celami zarządzania przedsiębiorstwem. Funkcje zarządzania rozwojem przedsiębiorstw wydawniczych i poligraficznych są analizowane w kontekście ich przynależności do przemysłów kreatywnych. Zarządzanie rozwojem przedsiębiorstw wydawniczych i poligraficznych ma na celu przejście do nowego stanu jakości, zwiększenie wydajności, konkurencyjności, wydłużenie cyklu życia, obopólnie korzystną integrację z podmiotami przemysłów kreatywnych.

Słowa kluczowe: rozwój, digitalizacja, zdolność zarobkowa, funkcje zarządcze, poligrafia, wydawnictwa, analiza SWOT 